\title{
Coronavirus disease (COVID-19): a scoping review
}

Meng Lv ${ }^{1,2,3}$, Xufei Luo ${ }^{1,2,3}$, Janne Estill4,5, Yunlan Liư ${ }^{1}$, Mengjuan Ren ${ }^{1}$, Jianjian Wang ${ }^{1,3}$, Qi Wang ${ }^{6}$, Siya Zha0 $0^{1,3}$, Xiaohui

Wang ${ }^{1}$, Shu Yang ${ }^{7}$, Xixi Feng ${ }^{8}$, Weiguo Li ${ }^{9,10}$, Enmei Liu ${ }^{9,10}$, Xianzhuo Zhang ${ }^{11}$, Ling Wang ${ }^{1}$, Qi Zhou ${ }^{11}$, Wenbo Meng ${ }^{12}$,

Xiaolong $\mathrm{Q}^{12}{ }^{12}$, Yangqin Xun ${ }^{3}$, Xuan Yu ${ }^{3}$, Yaolong Chen ${ }^{3,13,14,15,16}$, on behalf of the COVID-19 evidence and recommendations working group ${ }^{17}$

1. School of Public Health, Lanzhou University, Lanzhou, China

2. These authors contributed equally to this work and share first authorship

3. Evidence-based Medicine Center, School of Basic Medical Sciences, Lanzhou University, Lanzhou, China

4. Institute of Global Health, University of Geneva, Geneva, Switzerland

5. Institute of Mathematical Statistics and Actuarial Science, University of Bern, Bern, Switzerland

6. Department of Health Research Methods, Evidence and Impact, Faculty of Health Sciences, McMaster University, Hamilton, Canada

7. College of Medical Information Engineering, Chengdu University of Traditional Chinese Medicine, Chengdu, China

8. School of Public Health, Chengdu Medical College, Chengdu, China

9. Department of Respiratory Diseases, Children's Hospital of Chongqing Medical University, Chongqing, China

10. Chongqing Key Laboratory of Pediatrics, Chongqing, China

11. The First School of Clinical Medicine, Lanzhou University, Lanzhou, China

12. The First Hospital of Lanzhou University, Lanzhou, China

13. World Health Organization (WHO) Collaborating Centre for Guideline Implementation and Knowledge Translation, Lanzhou, China

14. Guideline International Network Asia, Lanzhou, China

15. Key Laboratory of Evidence Based Medicine and Knowledge Translation of Gansu Province, Lanzhou University, Lanzhou, China

16. Lanzhou University, an affiliate of the Cochrane China Network, Lanzhou, China

17. The study collaborators are acknowledged at the end of the article

Correspondence: Xiaohui Wang (wangxiaohui@lzu.edu.cn), Yaolong Chen (chenyaolong@lzu.edu.cn)

Citation style for this article:

Lv Meng, Luo Xufei , Estill Janne , Liu Yunlan, Ren Mengjuan, Wang Jianjian, Wang Qi , Zhao Siya , Wang Xiaohui , Yang Shu , Feng Xixi , Li Weiguo, Liu

Enmei, Zhang Xianzhuo, Wang Ling, Zhou Qi , Meng Wenbo, Qi Xiaolong, Xun Yangqin, Yu Xuan, Chen Yaolong, on behalf of the COVID-19 evidence and

recommendations working group . Coronavirus disease (COVID-19): a scoping review. Euro Surveill. 2020;25(15):pii=2000125. https://doi.org/10.2807/1560-7917.

ES.2020.25.15.2000125

Article submitted on 07 Feb 2020 / accepted on 16 Mar 2020 / published on 16 Apr 2020

Background: In December 2019, a pneumonia caused by a novel coronavirus (SARS-CoV-2) emerged in Wuhan, China and has rapidly spread around the world since then. Aim: This study aims to understand the research gaps related to COVID-19 and propose recommendations for future research. Methods: We undertook a scoping review of COVID-19, comprehensively searching databases and other sources to identify literature on COVID-19 between 1 December 2019 and 6 February 2020. We analysed the sources, publication date, type and topic of the retrieved articles/studies. Results: We included 249 articles in this scoping review. More than half $(59.0 \%)$ were conducted in China. Guidance/guidelines and consensuses statements $(n=56 ; 22.5 \%)$ were the most common. Most $(n=192 ; 77.1 \%)$ articles were published in peerreviewed journals, $35(14.1 \%)$ on preprint servers and $22(8.8 \%)$ posted online. Ten genetic studies (4.0\%) focused on the origin of SARS-CoV-2 while the topics of molecular studies varied. Nine of 22 epidemiological studies focused on estimating the basic reproduction number of COVID-19 infection $\left(R_{0}\right)$. Of all identified guidance/guidelines $(n=35)$, only ten fulfilled the strict principles of evidence-based practice. The number of articles published per day increased rapidly until the end of January.
Conclusion: The number of articles on COVID-19 steadily increased before 6 February 2020. However, they lack diversity and are almost non-existent in some study fields, such as clinical research. The findings suggest that evidence for the development of clinical practice guidelines and public health policies will be improved when more results from clinical research becomes available.

\section{Introduction}

A new type of coronavirus (severe acute respiratory syndrome coronavirus 2; SARS-CoV-2) that began in Wuhan, China in late 2019 has spread across the world since then. The virus has caused an outbreak of viral pneumonia, which has been named Coronavirus disease (COVID-19). As of 24:00 on 6 February 2020, over 31,000 cases and 636 deaths had been confirmed in China [1]. Furthermore, more than $1,770,000$ cases had been diagnosed in 213 countries, areas or territories as at 13 April 2020 [2]. On 23 January 2020, Chinese authorities imposed a lockdown of Wuhan [3]. On 30 January 2020, the World Health Organization (WHO) declared the outbreak a Public Health Emergency of International Concern (PHEIC) [4] and on 11 March 2020, a pandemic [5]. 


\section{FIGURE 1}

Flowchart of selection process for the scoping review of coronavirus disease (COVID-19) articles/studies and results, 1 December 2019-6 February 2020
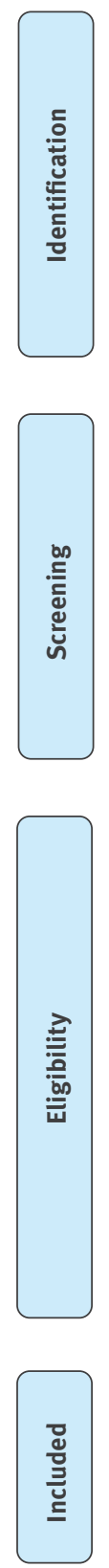

Records identified through database searching $(n=1,356)$

MEDLINE $(n=419)$, Web of Science $(n=344)$, Embase $(n=53)$, CNKI $(n=138)$, Wanfang Data $(n=235)$, CBM $(n=167)$
Additional records identified through other sources $(n=155)$
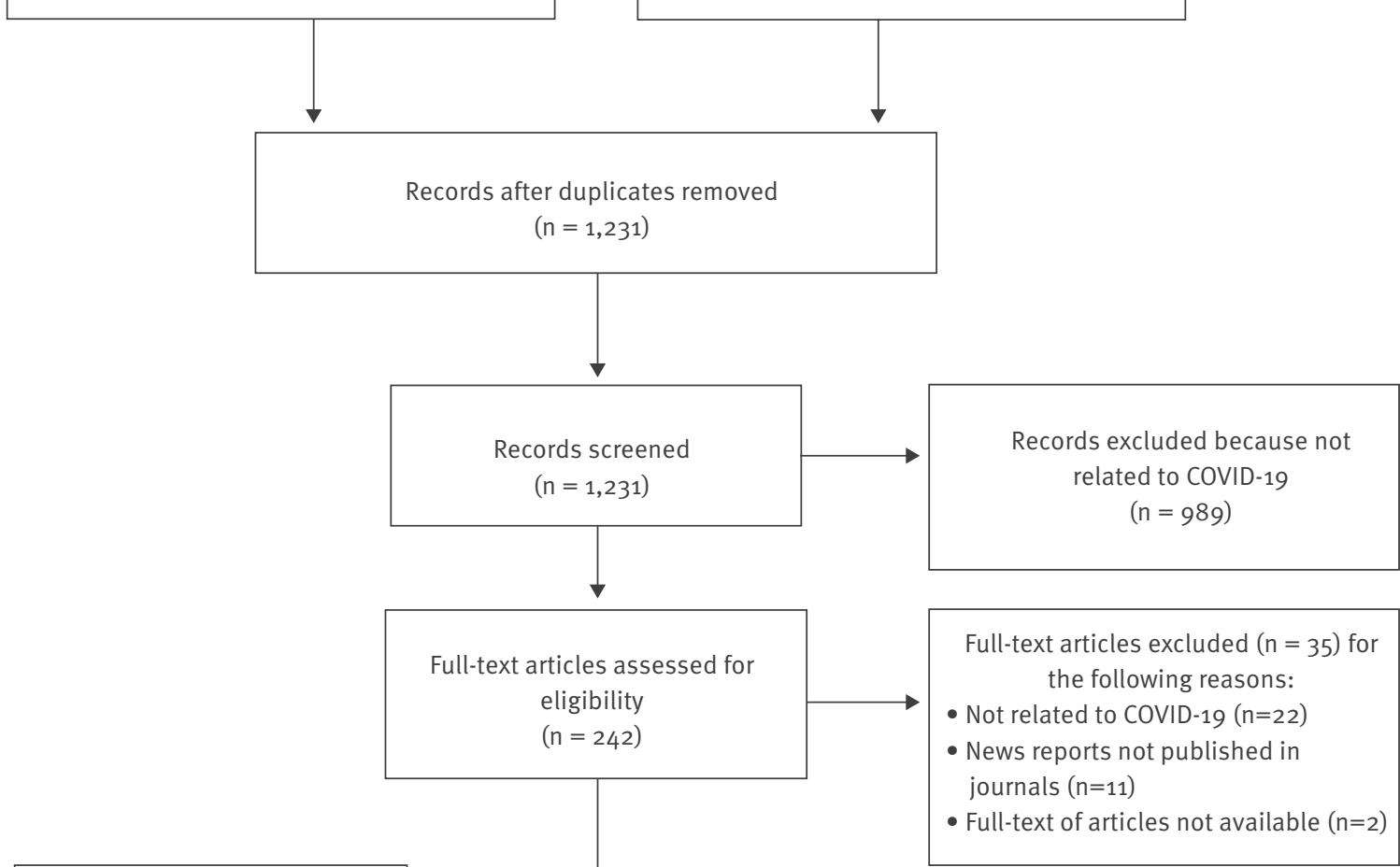

Additional records identified between 31 Jan and 6 Feb 2020 $(n=42)$

CBM: China Biology Medicine; CNKI: China National Knowledge Infrastructure.

The WHO [6-9], the United States (US) Centers for Disease Control and Prevention (CDC) $[10,11]$, the European Centre for Disease Prevention and Control (ECDC) $[12,13]$ as well as Chinese researchers have issued several guidance documents or guidelines to help address the outbreaks. Meanwhile, many scientific journals have rapidly published a number of articles, comments, editorials and perspectives related to COVID-19. It may however be challenging for the global research community to find all the available evidence: many of the first studies on COVID-19 were published in Chinese, and because of the rapidly developing situation, the latest studies are often available on websites or preprint servers only [14].
Scoping reviews are regarded as a valid tool to map the available evidence on a given topic, to clarify the characteristics of body of literature, to organise the key concepts and their relationship and to analyse knowledge gaps [15]. The methodology continues to be developed, and a Preferred Reporting Items for Systematic Reviews and Meta-Analyses (PRSIMA) extension for Scoping Reviews (PRISMA-SCR) including reporting guidance was published in 2018 [16]. Given the urgency of the COVID-19 epidemic and the need to understand and access information about it, a scoping review was considered suitable for the situation. We therefore conducted this scoping review to help identify research gaps related to this new viral disease 
and propose recommendations for future research on COVID-19.

\section{Methods}

\section{Search strategy}

We performed a systematic search of MEDLINE via PubMed, Embase, Web of Science, China National Knowledge Infrastructure (CNKI), Wanfang Data and China Biology Medicine (CBM) on 27 February 2020 with the terms "COVID-19" OR "SARS-CoV-2" OR "2019 novel coronavirus" OR "2019-nCoV” OR "Wuhan coronavirus" OR "novel coronavirus" OR "Wuhan seafood market pneumonia virus" OR "Wuhan virus", published between 1 December 2019 and 6 February 2020 (see Supplement $\mathrm{S}_{1}$ for details of search strategies). Because of potential delays in indexing of databases, we also searched selected infectious disease journals (Supplementary Table S1). We also searched Google Scholar; the official websites of WHO (https://www. who.int/), US CDC (https://www.cdc.gov/), ECDC (https://www.ecdc.europa.eu/en), Public Health England (PHE) (https://www.gov.uk/government/ organisations/public-health-england); some preprint servers, including BioRxiv (https://www.biorxiv.org/), ChemRxiv (https://chemrxiv.org/), medRxiv (https:// www.medrxiv.org/) and SSRN (https://www.ssrn.com/ index.cfm/en/); and reference lists of the identified articles to find reports of additional studies.

\section{Inclusion and exclusion criteria}

We included all literature related to COVID-19 published in English and Chinese between 1 December 2019 and 6 February 2020 without restrictions, including guidance/guidelines, reviews, clinical studies, basic research, epidemiological studies and comments. Documents and guidance/guidelines posted by international organisations, government institutions, associations and societies were also included. We excluded news reports that were not published in scientific journals, and articles where we failed to access full text despite contacting the authors.

\section{Article selection and data extraction}

Two reviewers ( $M L$ and $\mathrm{XL}$ ) screened all titles, abstracts and full texts independently and solved disagreements by consensus or consultation with a third reviewer. Then the following information was extracted: (i) title, (ii) first author, (iii) whether peer-reviewed or not, (iv) journal, (v) publication or posted date, (vi) first author's country (or international organisation), (vii) type of article/study and (viii) topic. The details are shown in Supplementary Table S2.

\section{Data analysis}

We conducted a descriptive analysis of the characteristics of the included literature. We described the source where we found the article, publication date, type of article/study, and topic of article/study or guidance/ guideline on COVID-19 to examine the existing gaps in research. We categorised the literature into guidance/ guidelines and consensus statements, reviews, clinical studies (including randomised controlled trials and observational studies), basic research, epidemiological studies, editorial comments on COVID-19 and other categories if identified. We conducted this scoping review in accordance with the PRISMA-ScR Checklist [16] (Supplementary Table S3).

\section{Results}

\section{Search results}

We identified 1,511 records, 280 of which were excluded as duplicates. Title and abstract screening were conducted for the remaining 1,231 articles, 989 of which were excluded because of being unrelated to COVID19. For two articles, we failed to access the full text after contacting the authors. We retrieved the full texts of the 242 remaining articles. After further screening and supplementary searching of articles published or posted between 31 January 2020 and 6 February 2020, we identified an additional 42 articles and a total of 249 articles were included in the review (Figure 1).

\section{Characteristics of included articles/studies}

Of the 249 included articles/studies, 147 (59.0\%) were from China. The article/study type varied vastly, which we broadly characterised into 11 types (Table 1). Of these, guidance/guidelines and consensuses statements were the most common $(n=56 ; 22.5 \%)$.

\section{Sources of articles/studies}

Of all included articles/studies, 192 (77.1\%) were published in peer-reviewed journals, 35 (14.1\%) were posted on preprint servers and 22 (8.8\%) were published on the official websites of public health organisations. The journal with the highest number of articles was The Lancet, with $13(6.8 \%)$ published articles. Of preprint articles, most $(n=28)$ were posted on BioRxiv. Articles published on official websites were mainly COVID-19 guidance/guidelines, including 10 WHO interim guidance documents, nine US CDC interim guidelines/guidance documents, two ECDC guidance documents and one Communicable Diseases Network Australia (CNDA) guideline.

\section{Publication date}

Figure 2 shows the cumulative number of articles published daily between 10 January 2020 and 6 February 2020. As at 6 February 2020, the number of articles on COVID-19 had been steadily increasing. Of the 192 articles that were published in peer-reviewed journals, the highest number of journal publications on a single day was on 30 January, with 24 articles $(12.5 \%)$. For the 35 preprints, the number posted per day rose steadily from 19 January 2020 to 6 February 2020.

\section{Type of article/study}

The types of articles/studies published on each day are shown in Figure 3. The daily number of guidance/ guidelines peaked between 29 January and 3 February 
TABLE 1A

Characteristics of the coronavirus disease (COVID-19) articles/studies included in the scoping review, 10 January-6 February $2020(n=249)$

\begin{tabular}{|c|c|c|c|}
\hline \multicolumn{2}{|l|}{ Characteristic } & \multirow{2}{*}{$\begin{array}{c}\begin{array}{c}\text { Number of articles/ } \\
\text { studies }\end{array} \\
192 \\
\end{array}$} & \multirow{2}{*}{$\begin{array}{c}\text { Percentage (\%) } \\
77.1 \\
\end{array}$} \\
\hline Publication nlatform & Journal & & \\
\hline Pupication platrorm & Other than journal ${ }^{a}$ & 57 & 22.9 \\
\hline \multirow{21}{*}{ Journal $(n=192)$} & The Lancet & 13 & 6.8 \\
\hline & Journal of Medical Virology & 12 & 6.3 \\
\hline & New Medicine & 9 & 4.7 \\
\hline & The New England Journal of Medicine & 9 & 4.7 \\
\hline & Eurosurveillance & 8 & 4.2 \\
\hline & Journal of Traditional Chinese Medicine & 7 & 3.6 \\
\hline & British Medical Journal (BMJ) & 7 & 3.6 \\
\hline & Radiology & 5 & 2.6 \\
\hline & Travel Medicine and Infectious Disease & 5 & 2.6 \\
\hline & Chinese Nursing Research & 5 & 2.6 \\
\hline & Chinese Journal of Tuberculosis and Respiration & 4 & 2.1 \\
\hline & Nature & 4 & 2.1 \\
\hline & Chinese Journal of Contemporary Paediatrics & 3 & 1.6 \\
\hline & Emerging Microbes and Infections & 3 & 1.6 \\
\hline & The Journal of the American Medical Association (JAMA) & 3 & 1.6 \\
\hline & Journal of Hospital Infection & 3 & 1.6 \\
\hline & Journal of Travel Medicine & 3 & 1.6 \\
\hline & Herald of Medicine & 3 & 1.6 \\
\hline & Chinese Journal of Emergency Medicine & 3 & 1.6 \\
\hline & Chinese Journal of Paediatrics & 3 & 1.6 \\
\hline & Other & 80 & 41.7 \\
\hline \multirow{7}{*}{$\begin{array}{l}\text { First author's country or } \\
\text { international organisation }\end{array}$} & China & 147 & 59.0 \\
\hline & United States & 33 & 13.3 \\
\hline & United Kingdom & 16 & 6.4 \\
\hline & WHO & 10 & 4.0 \\
\hline & Canada & 7 & 2.8 \\
\hline & Germany & 6 & 2.4 \\
\hline & Other & 30 & 12.1 \\
\hline \multirow{5}{*}{ Publication or posted date } & $10-15 \operatorname{Jan}$ & 6 & 2.4 \\
\hline & $16-20$ Jan & 7 & 2.8 \\
\hline & $21-25$ Jan & 38 & $15 \cdot 3$ \\
\hline & 26-31 Jan & 93 & $37 \cdot 3$ \\
\hline & $1-6 \mathrm{Feb}$ & 105 & 42.2 \\
\hline
\end{tabular}

SARS-CoV-2: severe acute respiratory syndrome coronavirus 2; WHO: World Health Organization.

${ }^{a}$ Includes the websites of WHO, United States Centers for Disease Control and Prevention (US CDC), European Centre for Disease Prevention and Control (ECDC) and Public Heath England (PHE), and preprint servers.

whereas the number of published reviews showed an increasing trend since 29 January 2020. Only one systematic review was identified [17]. We found no randomised controlled studies or cohort studies.

\section{Topics}

The different types of articles/studies focused on different topics. The basic research could be divided broadly into two categories: 21 genetic studies and 12 molecular biology studies. Ten genetic studies traced the origin of SARS-CoV-2 and tried to determine the possible virus reservoir. Among these, most suggested that SARS-CoV-2 evolved from a bat-CoV, namely bat-SL-CoVZC 45, bat-SL-CoVZXC21, bat-SLCoVZX 45 and bat-CoV-RaTG13 as potential candidates [18-26]. However, Ji et al. [18] found snakes to be the most probable reservoir for SARS-CoV-2 while Guo et al. [26] suggested mink could be a candidate reservoir. Of the molecular studies, five [27-31] showed that the key receptor of SARS-CoV-2 is angiotensin converting enzyme 2 (ACE2), which is highly expressed in lung type II alveolar cells (AT2) [27], positive cholangiocytes [29], upper oesophagus, stratified epithelial cells and absorptive enterocytes from ileum and colon [30]. The other studies included an assessment of the cross-reactivity of anti-SARS-CoV antibodies with 
Characteristics of the coronavirus disease (COVID-19) articles/studies included in the scoping review, 10 January-6 February $2020(\mathrm{n}=249)$

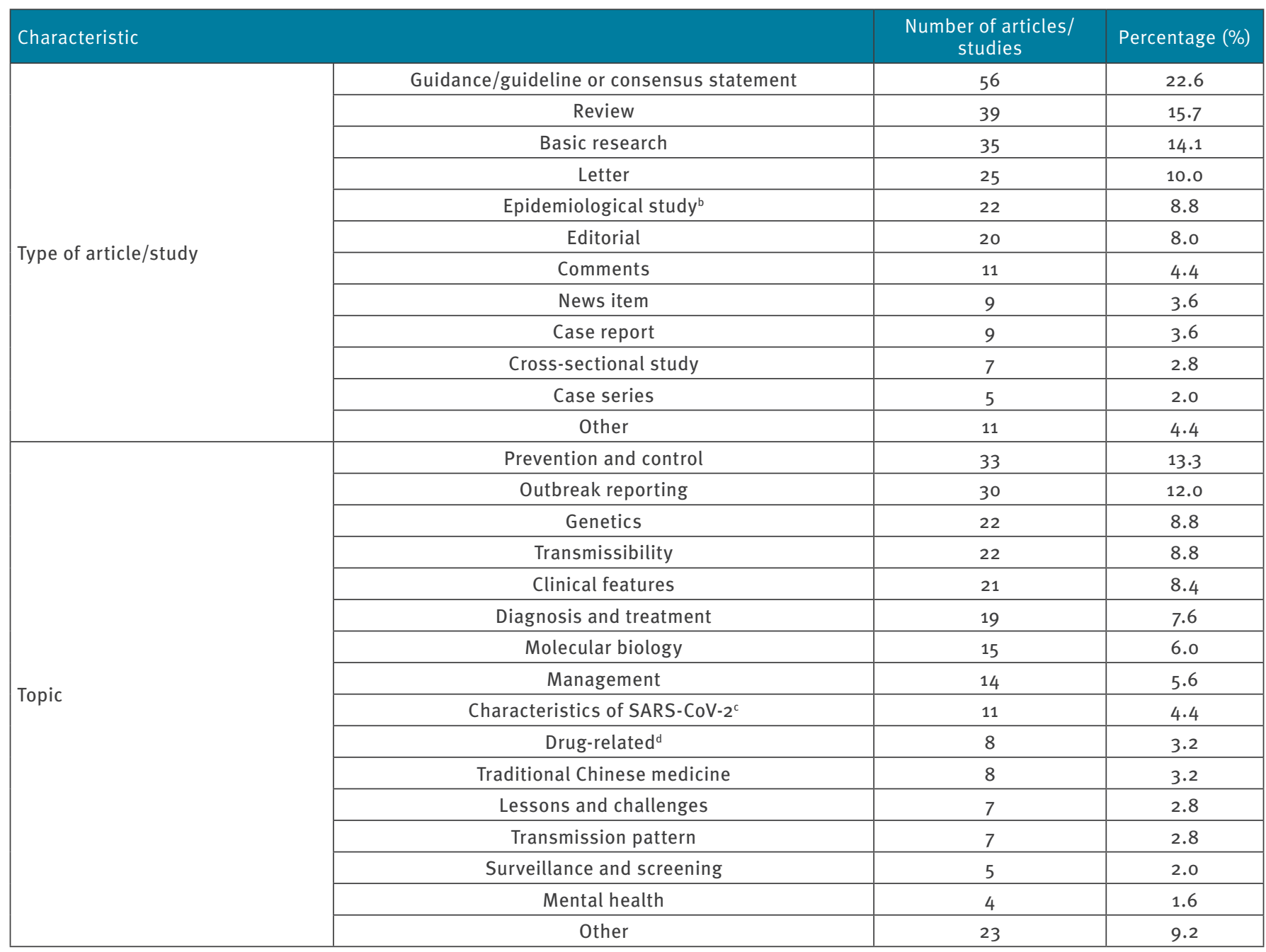

SARS-CoV-2: severe acute respiratory syndrome coronavirus 2; WHO: World Health Organization.

${ }^{b}$ Other than cross-sectional studies.

c Includes reviews and correspondence that discussed the characteristics of the virus in general.

${ }^{d}$ Other than traditional Chinese medicine.

SARS-CoV-2 spike protein [32], and SARS-CoV-2 main proteases [33,34].

The main topic of epidemiological studies was the estimation of the transmissibility of COVID-19. The value of the basic reproduction number $\left(R_{\mathrm{o}}\right)$ varied across studies [35-43], however, all estimated it to be higher than one, which indicates the potential for sustained human-to-human transmission. According to the nine articles [35-43], $R_{0}$ ranges between 2.2 and 3.9. Some studies showed that the transmissibility of SARS-CoV-2 is comparable to $[37,44]$ or even higher [39] than SARS$\mathrm{CoV}$ and Middle East respiratory syndrome coronavirus (MERS-CoV). In addition, studies focused on the disease burden associated with COVID-19 [45] and the global patterns of disease dispersion $[46,47]$.
Most reviews on COVID-19 gave a brief summary of the clinical features [48-51] and the characteristics of SARS-CoV-2 [52-54], as well as recommendations on how to prevent and control [55-60] this novel pneumonia. A systematic review [17] explored the possibility of using lopinavir/ritonavir (LPV/r) to treat COVID-19, with the results supporting the use of LPV/r as a part of an experimental regimen for COVID-19 pneumonia treatment. Clinical features were reported in 21 studies [48-51,61-77]. The main symptoms of patients with COVID-19 at onset were found to be fever and cough, with a reduced lymphocyte count, which is similar to previous beta coronavirus infections $[78,79]$.

Seventeen of the 56 editorials, comments and letters [80-96] were first reports or comments on the situation of the COVID-19 epidemic. Some [97-101] also briefly 
Cumulative number of coronavirus disease (COVID-19)-related articles/studies included in the scoping review, 10 January-6 February $2020(\mathrm{n}=249)$

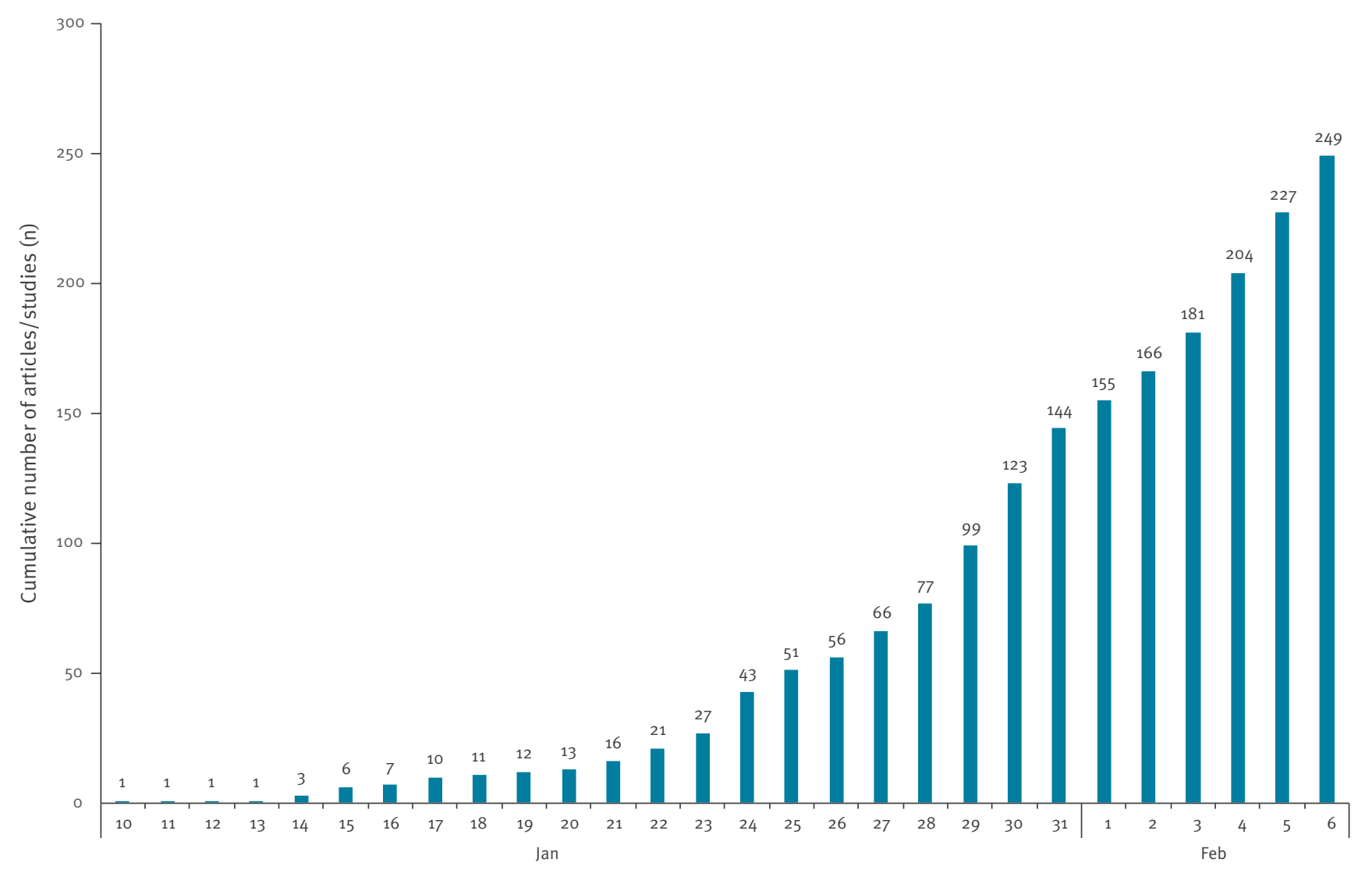

Date (2020)

introduced the general information and characteristics of the new virus. The mapping of article/study type and topics, as well as associated gaps, is shown in Table 2.

\section{Guidance/guidelines and consensus statements} Of the 56 published guidance/guidelines and consensuses statements, 35 were guidance/guidelines. Nine of the 35 addressed the treatment and management of COVID-19 infection, eight addressed prevention and five addressed diagnostics. Ten of the guidance/guidelines were interim guidance documents issued by the WHO, including those on COVID-19 prevention, surveillance, assessment, care, management and mask use [6-9,102-107]. The US CDC published nine interim guidance/guidelines documents for evaluating, preventing and managing the new coronavirus [10,11,108-114]. In addition, ECDC published two guidance documents about COVID-19 patient care and the management of persons having had contact with SARS-CoV-2 cases $[12,13]$. Chinese researches also published 14 rapidadvice guidance/guidelines documents on diagnosis, prevention and management of COVID-19, all of which were interim guidance/guidelines documents developed by hospitals [115-128].

Only eight of the guidance documents/guidelines formed a guideline development group (GDG) [129]; the recommendations of 15 guidance documents/ guidelines, including six developed by the WHO, were difficult to distinguish. Only ten guidance/guidelines fulfilled the strict principles of evidence-based practice and cited reference documents, which were mainly epidemic reports, government documents, and indirect evidence related to SARS-CoV or MERS-CoV $[6,7,105,116-118,120,122,125,126]$. Only two guidelines, both developed by Chinese researchers, were graded using the Grading of Recommendations Assessment, Development and Evaluation (GRADE) approach $[116,117]$. Among the 35 guidance/guidelines, one [115] was completely on Traditional Chinese medicine and one [116] covered Chinese medicine. One Australian guideline [130] was adapted from SARS-CoV guidelines.

\section{Discussion}

Our scoping review shows that while the number of articles on COVID-19 has been constantly increasing, as at 6 February, there were still clear gaps in several study types and research fields. We identified that some study types, in particular randomised controlled trials and cohort studies, were still non-existent before 6 February. According to a preliminary search of the Cochrane Network database up to 10 April 2020, the number of randomised controlled trials (RCTs) $(n=8)$ and observational studies $(n=42)$ still remains low [131]. 


\section{FIGURE 3}

Number of coronavirus disease (COVID-19)-related articles/studies published per day according to type, 10 January-6 February $2020(\mathrm{n}=249)$
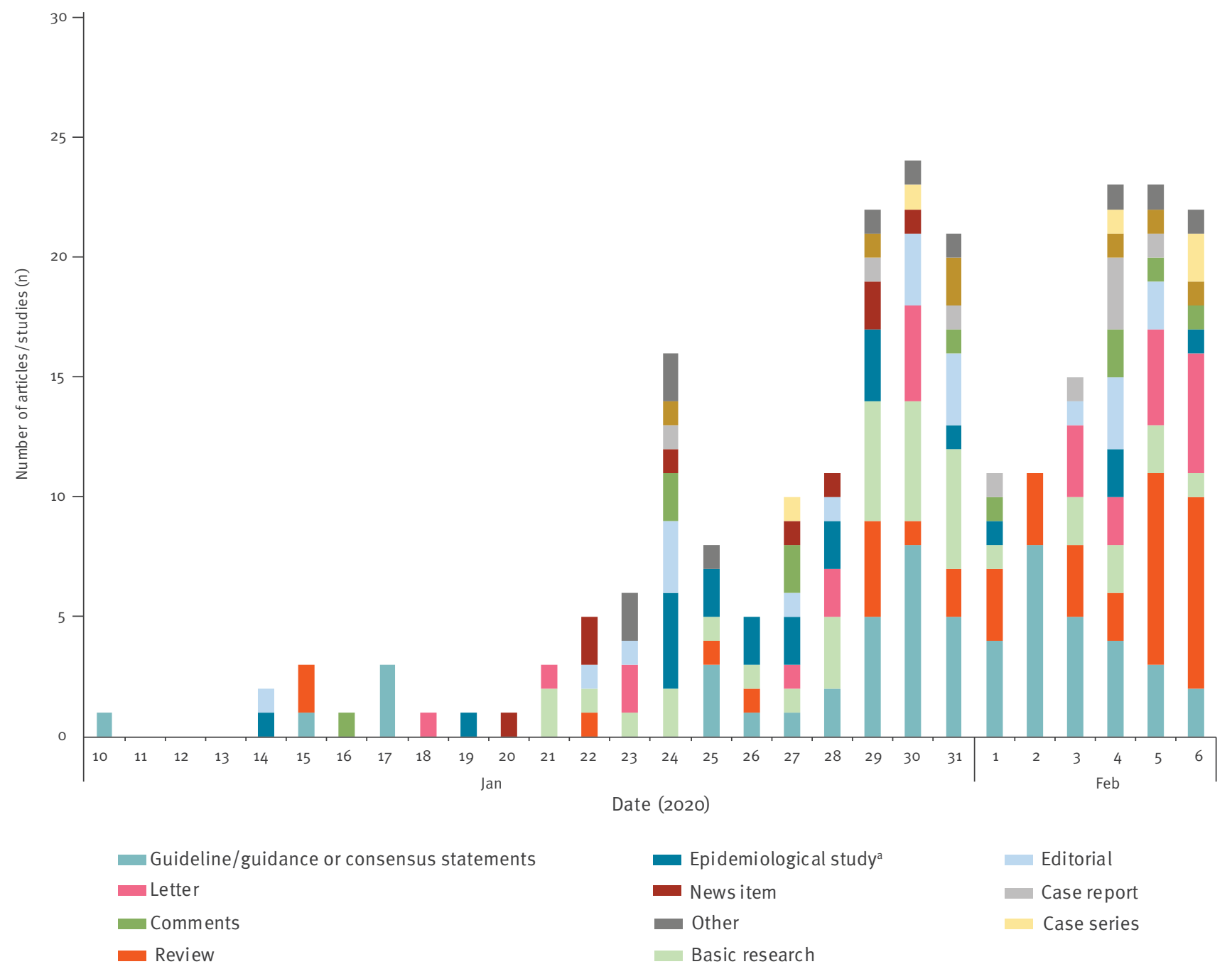

a Including cross-sectional studies.

We also found that there were only a few studies on clinical practice, making it difficult to develop clinical practice guidelines and health policies. The reason for the gaps in this area may be the rapid development of the outbreak and limited understanding of the new virus and the disease caused by it. Moreover, it takes time to conduct clinical research. When facing a public health emergency with a previously unknown cause, researchers should conduct studies on whether some clinical practice and public health interventions from other public health emergencies can be used as indirect evidence. However, we identified no such studies in our review.

We found that $14 \%$ of the studies related to COVID19 were posted on preprint servers. This approach of sharing research as quickly as possible is very reasonable, especially in the case of such public health emergency. Previous studies have shown that preprints can accelerate progress in handling outbreaks of infectious disease $[132,133]$.

The research topics in different types of articles/ studies had both similarities and differences. Basic research was mostly focused on exploring the origin and reservoirs of the new virus, while epidemiological studies mainly focused on its transmissibility. Reviews and reports provided more general information of the virus and the outbreak, while guidance/guidelines included recommendations on how to prevent and control it.

Clinical practice guidelines are statements that include recommendations intended to optimise patient care that are informed by a systematic review of evidence and an assessment of the benefits and harms of alternative care options [134]. Clinical practice guidelines can inform healthcare workers' actions [134], and, especially when public health emergencies occur, rapid 


\begin{tabular}{|c|c|c|c|c|c|c|c|c|c|c|c|c|}
\hline \multirow[b]{2}{*}{ Topic } & \multicolumn{12}{|c|}{ Article type } \\
\hline & $\begin{array}{l}\text { Guidance/ } \\
\text { guideline or } \\
\text { consensus } \\
\text { statement (n) }\end{array}$ & $\begin{array}{l}\text { Review } \\
\text { (n) }\end{array}$ & $\begin{array}{l}\text { Basic } \\
\text { research } \\
\text { (n) }\end{array}$ & $\begin{array}{l}\text { Letter } \\
\text { (n) }\end{array}$ & $\begin{array}{l}\text { Epidemiological } \\
\text { study }^{\mathrm{a}}(\mathrm{n})\end{array}$ & $\begin{array}{l}\text { Editorial } \\
\text { (n) }\end{array}$ & $\underset{(\mathrm{n})}{\text { Comments }}$ & $\begin{array}{l}\text { News } \\
\text { item } \\
\text { (n) }\end{array}$ & $\begin{array}{l}\text { Case } \\
\text { report } \\
\text { (n) }\end{array}$ & $\begin{array}{l}\text { Cross- } \\
\text { sectional } \\
\text { study (n) }\end{array}$ & $\begin{array}{l}\text { Case } \\
\text { series } \\
\text { (n) }\end{array}$ & Other $^{\mathrm{b}}(\mathrm{n})$ \\
\hline $\begin{array}{l}\text { Prevention and } \\
\text { control }\end{array}$ & 23 & 6 & 0 & 2 & 2 & 0 & 0 & 0 & 0 & 0 & 0 & 0 \\
\hline Outbreak reporting & 0 & 0 & 0 & 3 & 0 & 10 & 4 & 9 & o & 0 & o & 4 \\
\hline Genetics & 0 & 1 & 21 & & 0 & 0 & 0 & 0 & 0 & 0 & o & o \\
\hline Transmissibility & 0 & 1 & o & 4 & 13 & 3 & 0 & o & 0 & 0 & 1 & 0 \\
\hline Clinical features & 0 & 4 & 0 & 2 & o & 0 & 2 & o & 5 & 2 & 4 & 2 \\
\hline $\begin{array}{l}\text { Diagnosis and } \\
\text { treatment }\end{array}$ & 11 & 3 & 0 & 1 & 0 & 1 & 0 & o & 2 & 0 & 0 & 1 \\
\hline Molecular biology & 0 & 2 & 12 & 1 & 0 & 0 & 0 & 0 & 0 & 0 & o & 0 \\
\hline Management & 12 & 2 & 0 & & o & 0 & 0 & o & 0 & 0 & o & 0 \\
\hline $\begin{array}{l}\text { Characteristics of } \\
\text { SARS-CoV-2 }\end{array}$ & 0 & 4 & 0 & 1 & 0 & 3 & 1 & o & 1 & 0 & o & 1 \\
\hline Drug-related $^{c}$ & 0 & 2 & 2 & 3 & 0 & 0 & 0 & o & 0 & 0 & o & 1 \\
\hline $\begin{array}{l}\text { Traditional Chinese } \\
\text { medicine }\end{array}$ & 0 & 8 & 0 & & 0 & 0 & 0 & 0 & 0 & 0 & o & 0 \\
\hline $\begin{array}{l}\text { Lessons and } \\
\text { challenges }\end{array}$ & 0 & 3 & 0 & 1 & 0 & 0 & 3 & 0 & 0 & 0 & 0 & 0 \\
\hline $\begin{array}{l}\text { Transmission } \\
\text { pattern }\end{array}$ & 0 & 0 & 0 & 2 & 4 & 0 & 0 & 0 & 1 & 0 & 0 & 0 \\
\hline $\begin{array}{l}\text { Surveillance and } \\
\text { screening }\end{array}$ & 2 & 0 & 0 & 3 & 0 & 0 & 0 & 0 & 0 & 0 & 0 & 0 \\
\hline Mental health & 0 & 0 & o & 1 & 0 & 0 & 1 & 0 & 0 & 2 & o & 0 \\
\hline Other ${ }^{d}$ & 8 & 3 & 0 & 1 & 3 & 3 & 0 & 0 & 0 & 3 & 0 & 2 \\
\hline
\end{tabular}

a Other than cross-sectional studies.

b Includes perspectives, case-control study and investigation protocols.

c Other than traditional Chinese medicine.

${ }^{d}$ Guidance/guideline or consensus statement: guidance for laboratory biosafety, caring and travellers, and national capacity review tools; review: reviews on human resources of healthcare, the causes and counter-measures of Wuhan 'stigma', and public health; letter: outbreak assessment; epidemiology study: studies on disease burden, the number of unreported cases, and infection fatality; editorial: journal's opinion on matters related to COVID-19, and incidence rate estimation; cross-sectional study: hazard vulnerability analyses, epidemiology reports, and studies on public attitudes and perception; other: investigation protocol.

advice guidelines can guide clinicians in terms of how to perform related work [135]. After the outbreak of COVID-19, the WHO, US CDC and ECDC released guidance/guidelines as soon as possible, as did several Chinese institutions. However, most of these documents did not establish formal guideline development groups, and they did not fulfil the strict principles of evidence-based practice. For example, most guidance/ guidelines did not grade the quality of evidence and strength of recommendations, and thus owed to the emerging crisis, such guidance/guidelines need to be considered with these limitations in mind. In 2007, the WHO published guidance about the process of developing rapid advice guidelines [129], stating that when a public health emergency occurs, a rapid review is needed and the development time should not exceed 6 months [135]. However, considering the limited time to set up panels, this could be a challenge for guidance/ guideline developers. Nonetheless, we still expect guidance/guideline developers to establish formal development groups and fulfil the evidence-based practice principles.
Our scoping review can help researchers identify research gaps so as to conduct research to fill these gaps. For example, in the current situation, a systematic review to estimate the incubation period or research on new drugs or treatments, would be of great importance. This scoping review has several strengths. We performed a systematic search of a comprehensive set of sources, including databases, preprint servers, and official websites of international organisations and associations at the early stage of the pandemic. Furthermore, our large sample size is sufficient to illustrate the state of research and identify research gaps related to COVID-19 at the onset of the pandemic.

This study also has some limitations. Because of the delay in indexing, some articles published as at 6 February 2020 may not have been identified. Also, because our retrieval time was only until this date, articles published or posted after this date, of which there have been many, have not been included in the analysis. As some preprints, guidance/guidelines and disease control plans are constantly updated, the publication date we extracted may not be the time of their first publication time. Also, we did not assess the 
quality of the included literature because of diversity of the types of included articles. Another limitation of our study was that it only included articles published in English and Chinese, which could introduce publication bias. However, as the epidemic was most heavily affecting China until early February, it is reasonable to expect that literature published in English and Chinese up until this point in time covered the majority of the available knowledge. Finally, we were unable to access the full texts of two articles despite contacting the authors. However, compared with the total number of articles included in the review, we anticipate that the exclusion of these two articles is unlikely to have a major impact.

\section{Conclusion}

This scoping review shows the state of literature published or posted online related to COVID-19 as at 6 February 2020. The number of articles in this field has steadily increased since the outbreak became evident. However, the types of studies lacked diversity, especially clinical studies. More clinical research is needed, but in the rapidly evolving global pandemic, we encourage researchers to continuously review the latest literature, to take into account the latest available evidence and avoid overlapping work, and to improve evidence for the development of clinical practice guidelines and public health policies.

\section{Acknowledgements}

Funding statement: 2020 Key R \& D project of Gansu Province; Special funding for prevention and control of emergency of COVID-19 from Key Laboratory of Evidence Based Medicine and Knowledge Translation of Gansu Province (No. GSEBMKT-2020YJ01).

The members of the COVID-19 evidence and recommendations working group: Xiao Liu (Evidence-based Medicine Center, School of Basic Medical Sciences, Lanzhou University, Lanzhou, China); Nan Yang (Evidence-based Medicine Center, School of Basic Medical Sciences, Lanzhou University, Lanzhou, China); Shuya Lu (Sichuan Provincial People's hospital, Chengdu, China ); Peipei Du ( School of Public Health, Chengdu Medical College, Chengdu, China); Yanfang Ma (Evidence-based Medicine Center, School of Basic Medical Sciences, Lanzhou University, Lanzhou, China); Zijun Wang (Evidence-based Medicine Center, School of Basic Medical Sciences, Lanzhou University, Lanzhou, China); Qianling Shi (The First School of Clinical Medicine, Lanzhou University, Lanzhou, China); Hairong Zhang (Evidence-based Medicine Center, School of Basic Medical Sciences, Lanzhou University, Lanzhou, China); Qiangqiang Guo (School of Public Health, ShanXi Medical University, Taiyuan,China); Yuting Yang (Children's Hospital of Chongqing Medical University, Chongqing, China); Bo Yang (Children's Hospital of Chongqing Medical University, Chongqing, China); Shouyuan Wu (School of Public Health, Lanzhou University, Lanzhou, China); Xiaoqin Wang (Michael G. DeGroote Institute for Pain Research and Care, McMaster University, Hamilton, Ontario, Canada).

\section{Conflict of interest}

None declared.
Authors' contributions

All authors have read and agree to the published version of the manuscript. Conceptualisation, YC and XW; methodology, ML, XL and JE; software, YL, MR and JW; data extraction, QW, SZ, MR, XZ, LW, QZ and SY; formal analysis, XL and ML; resources, $M L$ and $W L$; writing-original draft preparation, $M L, X L, W M$ and $X Q$; writing-review and editing, $Y X, X Y$, $Y C, X W, S Y, X F, W M$, JE, EL and $X Q$; visualisation, $M L$ and $X L$; supervision, $Y C$ and $X W$; project administration, $Y C$; funding acquisition, YC.

\section{References}

1. National Health Commission of the People's Republic of China (NHC PRC). Feb 7: Daily briefing on novel coronavirus cases in China. Beijing: NHC PRC; 7 Feb 2020. Available from: http:// en.nhc.gov.cn/2020-02/07/c_76323.htm

2. World Health Organization (WHO). Coronavirus disease (COVID-19) outbreak situation. Geneva: WHO. [Accessed 14 April 2020]. Available from: https://www.who.int/emergencies/ diseases/novel-coronavirus-2019

3. National Health Commission of the People's Republic of China (NHC PRC). Timeline of China's fight against the novel coronavirus. Beijing: NHC PRC; 24 Jan 2020. Available from: http://en.nhc.gov.cn/2020-03/20/c 78021.htm

4. World Health Organization (WHO). Statement on the second meeting of the International Health Regulations (2005) Emergency Committee regarding the outbreak of novel coronavirus (2019-nCoV). Geneva: WHO; 30 Jan 2020. Available from: https://www.who.int/news-room/ detail/30-01-2020-statement-on-the-second-meeting-of-theinternational-health-regulations-(2005)-emergency-committeeregarding-the-outbreak-of-novel-coronavirus-(2019-ncov)

5. World Health Organization (WHO). WHO Director-General's opening remarks at the media briefing on COVID-19-11 March 2020. Geneva: 11 Mar 2020. Available from: https://www. who.int/dg/speeches/detail/who-director-general-s-openingremarks-at-the-media-briefing-on-covid-19---11-march-2020.

6. World Health Organization (WHO). Infection prevention and control during health care when novel coronavirus (nCoV) infection is suspected. Interim guidance. Geneva: WHO. [Accessed 25 Jan 2020]. Available from: https://www.who.int/ publications-detail/infection-prevention-and-control-duringhealth-care-when-novel-coronavirus-(ncov)-infection-issuspected-20200125

7. World Health Organization (WHO). Home care for patients with suspected novel coronavirus ( $\mathrm{nCoV}$ )infection presenting with mild symptoms and management of contacts. Interim guidance. Version 1. Geneva: WHO; 20 Jan 2020. Available from: https://reliefweb.int/sites/reliefweb.int/files/ resources/20200120-ncov-home-care-infected-patients.pdf

8. World Health Organization (WHO). Risk communication and community engagement (RCCE) readiness and initial response for novel coronaviruses (nCoV): Interim guidance. Geneva: WHO; 26 Jan 2020. Available from: https://apps.who.int/iris/ handle/10665/330377

9. World Health Organization (WHO). Laboratory testing of 2019 novel coronavirus (2019-nCoV) in suspected human cases. Interim guidance. Geneva: WHO; 17 Jan 2020. Available from: https://www.healthynewbornnetwork.org/hnn-content/ uploads/Interim-laboratory-eng.pdf

10. United States Centers for Disease Control and Prevention (US CDC). Interim Infection Prevention and Control Recommendations for Patients with Suspected or Confirmed 2019 Coronavirus Disease 2019 (COVID-19)in Healthcare Settings. Atlanta: US CDC. [Accessed 6 Feb 2020]. Available from: https://www.cdc.gov/coronavirus/2019-ncov/infectioncontrol/control-recommendations.html

11. United States Centers for Disease Control and Prevention (US CDC). Interim Guidance for Implementing Home Care of People Not Requiring Hospitalization for Coronavirus Disease 2019 (COVID-19). Atlanta: US CDC. [Accessed 6 Feb 2020]. Available from: https://www.cdc.gov/coronavirus/2019-ncov/hcp/ guidance-home-care.html

12. European Centre for Disease Prevention and Control (ECDC). Contact tracing: Public health management of persons, including healthcare workers, having had contact with COVID-19 cases in the European Union. Stockholm: ECDC. [Accessed 6 Feb 2020]. Available from: https://www.ecdc. europa.eu/en/publications-data/public-health-managementpersons-having-had-contact-novel-coronavirus-cases

13. European Centre for Disease Prevention and Control (ECDC). Infection prevention and control for the care of patients 
with 2019-nCoV in healthcare settings. Stockholm: ECDC; 2 Feb 2020. Available from: https://www.ecdc.europa.eu/en/ publications-data/infection-prevention-and-control-carepatients-2019-ncov-healthcare-settings

14. Johansson MA, Reich NG, Meyers LA, Lipsitch M. Preprints: An underutilized mechanism to accelerate outbreak science. PLoS Med. 2018;15(4):e1002549. https://doi.org/10.1371/journal. pmed.1002549 PMID: 29614073

15. Munn Z, Peters MDJ, Stern C, Tufanaru C, McArthur A, Aromataris E. Systematic review or scoping review? Guidance for authors when choosing between a systematic or scoping review approach. BMC Med Res Methodol, 2018;18(1):143. https://doi.org/10.1186/s12874-018-0611-x PMID: 30453902

16. Tricco AC, Lillie E, Zarin W, O’Brien KK, Colquhoun H, Levac D, et al. PRISMA Extension for Scoping Reviews (PRISMA-ScR): Checklist and Explanation. Ann Intern Med. 2018;169(7):46773. https://doi.org/10.7326/M18-0850 PMID: 30178033

17. Jiang H, Deng HF, Wang Y, Liu Z, Sun MW, Zhou P, et al. [The possibility of using Lopinave/Litonawe (LPV/r) as treatment for novel coronavirus 2019-nCov pneumonia: a quick systematic review based on earlier coronavirus clinical studies]. Chin J Emerg Med. 2020;29(2):182-6. Chinese. Available from: http:// rs.yiigle.com/yufabiao/1179572.htm

18. Ji W, Wang W, Zhao X, Zai J, Li X. Cross-species transmission of the newly identified coronavirus 2019-nCoV. J Med Virol. 2020;92(4):433-40. https://doi.org/10.1002/jmv.25682 PMID: 31967321

19. Chen JY, Shi JS, Qiu DA, Liu C, Li X, Zhao Q, et al. [Bioinformatics analysis of the 2019 novel coronavirus genome]. J Bioinform. 2020;01(01):1-10. Chinese. Available from: http://kns.cnki.net/kcms/detail/23.1513 Q.20200120.0839.002.html

20. Wu F, Zhao S, Yu B, Chen YM, Wang W, Hu Y, et al. Complete genome characterisation of a novel coronavirus associated with severe human respiratory disease in Wuhan, China. bioRxiv. 2020;919183: (Preprint). Available from: http://dx.doi. org/10.1101/2020.01.24.919183

21. Dong N, Yang X, Ye L, Chen K, Chan EWC, Yang M, et al. Genomic and protein structure modelling analysis depicts the origin and infectivity of 2019-nCoV, a new coronavirus which caused a pneumonia outbreak in Wuhan, China. bioRxiv. 2020;913368: (Preprint). Available from: http://dx.doi. org/10.1101/2020.01.20.913368

22. Paraskevis D, Kostaki EG, Magiorkinis G, Panayiotakopoulos G, Sourvinos G, Tsiodras S. Full-genome evolutionary analysis of the novel corona virus (2019-nCoV) rejects the hypothesis of emergence as a result of a recent recombination event. Infect Genet Evol. 2020;79:104212. https://doi.org/10.1016/j. meegid.2020.104212 PMID: 32004758

23. Stoermer M. Homology Models of Wuhan Coronavirus 3CLpro Protease. ChemRxiv. 2020;11637294: (Preprint). Available from: http://dx.doi.org/10.26434/chemrxiv.11637294.v1

24. Chan JF, Kok KH, Zhu Z, Chu H, To KK, Yuan S, et al. Genomic characterization of the 2019 novel human-pathogenic coronavirus isolated from a patient with atypical pneumonia after visiting Wuhan. Emerg Microbes Infect. 2020;9(1):22136. https://doi.org/10.1080/22221751.2020.1719902 PMID: 31987001

25. Ramaiah A, Arumugaswami V. Insights into Cross-species Evolution of Novel Human Coronavirus 2019-nCoV and Defining Immune Determinants for Vaccine Development. bioRxiv. 2020;925867: (Preprint). Available from: http://dx.doi. org/10.1101/2020.01.29.925867

26. Guo Q, Li M, Wang CH, Wang PH, Fang ZC, Tan J, et al. Host and infectivity prediction of Wuhan 2019 novel coronavirus using deep learning algorithm. bioRxiv. 2020;914044: (Preprint). Available from: http://dx.doi.org/10.1101/2020.01.21.914044

27. Zhao Y, Zhao ZX, Wang YJ, Zhou YQ, Ma Y, Zuo W. Single-cell RNA expression profiling of ACE2, the putative receptor of Wuhan 2019-nCov. bioRxiv. 2020;919985: (Preprint). Available from: http://dx.doi.org/10.1101/2020.01.26.919985

28. Wan Y, Shang J, Graham R, Baric RS, Li F. Receptor recognition by the novel coronavirus from Wuhan: an analysis based on decade-long structural studies of SARS coronavirus. I Virol. 2020;94(7):eo0127-20. https://doi.org/10.1128/JVI.00127-20 PMID: 31996437

29. Chai XQ, Hu LF, Zhang Y, Han WY, Lu Z, Ke A, et al. Specific ACE2 Expression in Cholangiocytes May Cause Liver Damage After 2019-nCoV Infection. bioRxiv. 2020;931766: (Preprint). Available from: http://dx.doi.org/10.1101/2020.02.03.931766

30. Zhang H, Kang ZJ, Gong HY, Xu D, Wang J, Li ZF, et al. The digestive system is a potential route of 2019-nCov infection a bioinformatics analysis based on single-cell transcriptomes. bioRxiv. 2020;927806: (Preprint). Available from: http://dx.doi. org/10.1101/2020.01.30.927806
31. Yang M, Zhao JM, Zhang Z. More Than Pneumonia, The Potential Occurrence of Multiple Organ Failure in 2019 Novel Coronavirus Infection. SSRN. 2020;3532272: (Preprint). Available from: http://dx.doi.org/10.2139/ssrn.3532272

32. Tian X, Li C, Huang A, Xia S, Lu S, Shi Z, et al. Potent binding of 2019 novel coronavirus spike protein by a SARS coronavirusspecific human monoclonal antibody. Emerg Microbes Infect. 2020;9(1):382-5. https://doi.org/10.1080/22221751.2020.1729 069 PMID: 32065055

33. Xu ZJ, Peng C, Shi YL, Zhu ZD, Mu KJ, Wang XY, et al. Nelfinavir was predicted to be a potential inhibitor of 2019-nCov main protease by an integrative approach combining homology modelling, molecular docking and binding free energy calculation. bioRxiv. 2020;921627: (Preprint). Available from: http://dx.doi.org/10.1101/2020.01.27.921627

34. Li Y, Zhang JY, Wang N, Li HO, Shi Y, Guo G, et al. Therapeutic Drugs Targeting 2019-nCoV Main Protease by High-Throughput Screening. bioRxiv. 2020;922922: (Preprint). Available from: http://dx.doi.org/10.1101/2020.01.28.922922

35. Zhou T, Liu QH, Yang ZM, Liao JY, Yang KX, Bai W, et al. [Preliminary Prediction of the basic reproduction number of the Wuhan novel coronavirus 2019[nCoV]. J Evid Based Med. 2020;20(3): 359-364. Chinese. Available from: https://doi. org/10.7507/1672-2531.202001118

36. Wu JT, Leung K, Leung GM. Nowcasting and forecasting the potential domestic and international spread of the 2019-nCoV outbreak originating in Wuhan, China: a modelling study. Lancet. 2020;395(10225):689-97. https://doi.org/10.1016/ S0140-6736(20)30260-9 PMID: 32014114

37. Shen MW, Peng ZH, Xiao YN, Zhang L. Modelling the epidemic trend of the 2019 novel coronavirus outbreak in China. bioRxiv. 2020;916726: (Preprint). Available from: http://dx.doi. org/10.1101/2020.01.23.916726

38. Riou J, Althaus CL. Pattern of early human-to-human transmission of Wuhan 2019 novel coronavirus (2019nCoV), December 2019 to January 2020. Euro Surveill. 2020;25(4):2000058. https://doi.org/10.2807/1560-7917. ES.2020.25.4.2000058 PMID: 32019669

39. Read J M, Bridgen J R, Cummings D A, Ho A, Jewell C P. Novel coronavirus 2019-nCoV: early estimation of epidemiological parameters and epidemic predictions. medRxiv. 2020;20018549: (Preprint). Available from: http://dx.doi. org/10.1101/2020.01.23.20018549

40. Majumder MS, Mandl KD. Early Transmissibility Assessment of a Novel Coronavirus in Wuhan, China. SSRN. 2020;3524675 (Preprint). Available from: http://dx.doi.org/10.2139/ ssrn.3524675

41. Liu T, Hu JX, Kang M, Li LF, Zhong HJ, Xiao JP, et al. Transmission Dynamics of 2019 Novel Coronavirus (2019nCoV). SSRN. 2020;3526307: (Preprint). Available from: http:// dx.doi.org/10.2139/ssrn.3526307

42. Li Q, Guan X, Wu P, Wang X, Zhou L, Tong Y, et al. Early Transmission Dynamics in Wuhan, China, of Novel CoronavirusInfected Pneumonia. N Engl J Med. 2020;382(13):1199-207. https://doi.org/10.1056/NEJMoa2001316 PMID: 31995857

43. Zhang C, Wang M. Origin time and epidemic dynamics of the 2019 novel coronavirus. bioRxiv. 2020;919688: (Preprint). Available from: http://dx.doi.org/10.1101/2020.01.25.919688v3

44. Zhang X, Wu K, Yue X, Zhu Y, Wu J. Inhibition of SARSCoV gene expression by adenovirus-delivered small hairpin RNA. Intervirology. 2007;50(2):63-70. https://doi. org/10.1159/000097391 PMID: 17139181

45. Ming W, Huang J, Zhang CJP. Breaking down of healthcare system: Mathematical modelling for controlling the novel coronavirus (2019-nCoV) outbreak in Wuhan, China. bioRxiv. 2020;922443: (Preprint). Available from: http://dx.doi. org/10.1101/2020.01.27.922443V1

46. Bogoch II, Watts A, Thomas-Bachli A, Huber C, Kraemer MUG, Khan K. Potential for global spread of a novel coronavirus from China. J Travel Med. 2020;27(2):taaa011. https://doi. org/10.1093/jtm/taaa011 PMID: 31985790

47. Bogoch II, Watts A, Thomas-Bachli A, Huber C, Kraemer MUG, Khan K. Pneumonia of unknown aetiology in Wuhan, China: potential for international spread via commercial air travel. Travel Med. 2020;27(2):taaaoo8. https://doi.org/10.1093/jtm/ taaaoo8 PMID: 31943059

48. Habibzadeh P, Stoneman EK. The novel coronavirus: a bird's eye view. Int J Occup Environ Med. 2020;11(2):65-71. https:// doi.org/10.15171/ijoem.2020.1921 PMID: 32020915

49. Shi HS, Han XY, Fan YQ, Liang B, Yang F, Han P, et al. [Radiologic Features of Patients with 2019-nCoV Infection]. Journal of Clinical Radiology. 2020;02(06):1-8. Chinese. Available from: https://doi.org/10.13437/j.cnki. jcr.20200206.002 
50. Fang F, Luo XP. [Facing the pandemic of 2019 novel coronavirus infections: the pediatric perspectives]. Zhonghua Er Ke Za Zhi. 2020;58(2):81-5. PMID: 32102140

51. Li L, Liu JJ, Jin RH, Li HJ. [The legal class B infectious disease the 2019 novel coronavirus (2019-nCoV) infected pneumonia in Wuhan, China: a review]. New Medicine. 2020;30(1):1421. Chinese. Available from: http://dx.doi.org/10.12173/j. issn.1004-5511.2020.01.06

52. Chen Y, Liu Q, Guo D. Emerging coronaviruses: Genome structure, replication, and pathogenesis. J Med Virol. 2020;92(4):418-23. https://doi.org/10.1002/jmv.25681 PMID: 31967327

53. Wen YM. [Pathogenicity, prevention and control of coronaviruses]. Journal of Microbes And Infections. 2020;15(1):5-12. Chinese. Available from: http://jmi.fudan.edu. $\mathrm{cn} / \mathrm{CN} /$ abstract/abstract816.shtml

54. Ralph R, Lew J, Zeng T, Francis M, Xue B, Roux M, et al. 2019$\mathrm{nCoV}$ (Wuhan virus), a novel Coronavirus: human-to-human transmission, travel-related cases, and vaccine readiness. I Infect Dev Ctries. 2020;14(1):3-17. https://doi.org/10.3855/ jidc.12425 PMID: 32088679

55. Zhang WF, He JM, Tie JF, Su YX, Ren Z. [Resistance and disinfection of Coronavirus]. Chinese Journal of Disinfection. 2020;37(1):63-67. Chinese. Available from: http://kns.cnki.net/ KCMS/detail/11.2672.R.20200130.1723.002.html

56. Liao X, Wang B, Kang Y. Novel coronavirus infection during the 2019-2020 epidemic: preparing intensive care units-the experience in Sichuan Province, China. Intensive Care Med. 2020;46(2):357-60. https://doi.org/10.1007/s00134-02005954-2 PMID: 32025779

57. Li D. [Community Pevention Guidance for Noval Coronavirus Pneumonia]. Herald of Medicine. 2020;39(03):315-318. Chinese. Available from: http://kns.cnki.net/kcms/detail/42.12 93.R.20200203.1403.004.html

58. Shen Y, Lu H. [Improving the understanding of diagnosis and treatment of novel coronavirus infection]. Chin J Infect Dis. 2020;38(01):6-8. Chinese. Available from: http://rs.yiigle.com/ CN311365202001/1183535.htm

59. Gong RR, Zhen Y, Wang YF, Tong F, Bai ZG, Campbell China Network. [The public perceptions of nonpharmaceutical interventions for reducing transmission of respiratory infection: an evidence policy brief for socia collaborative control of the new coronavirus (2019-nCoV) infected pneumonia]. New Medicine. 2020;30(02):8993. Chinese. Available from: https://doi.org/10.12173/j. issn.1004-5511.2020.02.02

6o. Yang Y, Cai HH, Geng Y. [Application of self-made protective face shield in protection of novel coronavirus pneumonia]. Infection, Inflammation, Repair. 2020; 02(02): 1-2. Chinese. Available from: http://kns.cnki.net/kcms/detail/11.5225 .R.20200202.1841.002.html

61. Backer JA, Klinkenberg D, Wallinga J. Incubation period of 2019 novel coronavirus (2019-nCoV) infections among travellers from Wuhan, China, 20-28 January 2020. Euro Surveill. 2020;25(5). https://doi.org/10.2807/1560-7917. ES.2020.25.5.2000062 PMID: 32046819

62. Ryu S, Chun BCKorean Society of Epidemiology 2019-nCoV Task Force Team. An interim review of the epidemiological characteristics of 2019 novel coronavirus. Epidemiol Health. 2020;42:e2020006. https://doi.org/10.4178/epih.e2020006 PMID: 32023775

63. Lei J, Li J, Li X, Qi X. CT imaging of the 2019 novel coronavirus (2019-nCoV) pneumonia. Radiology. 2020;295(1):18. https:// doi.org/10.1148/radiol.2020200236 PMID: 32003646

64. Kanne JP. Chest CT findings in 2019 novel coronavirus (2019-nCoV) infections from Wuhan, China: key points for the radiologist. Radiology. 2020;295(1):16-7. https://doi. org/10.1148/radiol.2020200241 PMID: 32017662

65. Chan JF, Yuan S, Kok KH, To KK, Chu H, Yang J, et al. A familial cluster of pneumonia associated with the 2019 novel coronavirus indicating person-to-person transmission: a study of a family cluster. Lancet. 2020;395(10223):514-23. https:// doi.org/10.1016/S0140-6736(20)30154-9 PMID: 31986261

66. Li L, Ren M, Zhang Y, Li W, Zhao H, Liang L, et al. [Lung CT image of a confirmed case of the 2019 novel coronavirus (2019-nCoV) infected pneumonia (With differential diagnosis of the SARS)]. New Medicine. 2020;30(1):4-6. Chinese. Available from: http://dx.doi.org/10.12173/j.issn.1004-5511.2020.01.03

67. Cai J, Wang X, Ge Y, Xia A, Chang H, Tian H, et al. [First case of 2019 novel coronavirus infection in children in Shanghai]. Chin J Pediatr. 2020;58(02):86-87. Chinese. Available from: http:// dx.doi.org/10.3760/cma.j.issn.0578-1310.2020.02.002

68. Liu P, Tan XZ. 2019 Novel Coronavirus (2019-nCoV) Pneumonia. Radiology. 2020;295(1):19. https://doi.org/10.1148/ radiol.2020200257 PMID: 32013795
69. Pan Y, Guan H. Imaging changes in patients with 2019-nCov. Eur Radiol. 2020. https://doi.org/10.1007/s00330-020-06713-z PMID: 32025790

70. Huang C, Wang Y, Li X, Ren L, Zhao J, Hu Y, et al. Clinical features of patients infected with 2019 novel coronavirus in Wuhan, China. Lancet. 2020;395(10223):497-506. https://doi. org/10.1016/S0140-6736(20)30183-5 PMID: 31986264

71. Chen N, Zhou M, Dong X, Qu J, Gong F, Han Y, et al. Epidemiological and clinical characteristics of 99 cases of 2019 novel coronavirus pneumonia in Wuhan, China: a descriptive study. Lancet. 2020;395(10223):507-13. https:// doi.org/10.1016/S0140-6736(20)30211-7 PMID: 32007143

72. Chung M, Bernheim A, Mei X, Zhang N, Huang M, Zeng X, et al. CT Imaging Features of 2019 Novel Coronavirus (2019nCoV). Radiology. 2020;295(1):202-7. https://doi.org/10.1148/ radiol.2020200230 PMID: 32017661

73. Wang W, Hu H, Song L, Gong X, Qu Y, Lu Z. [Image of pulmonary and diagnosis of atypical novel coronavirus (2019$\mathrm{n}(\mathrm{OV})$ infected pneumonia: case series of 14 patients]. New Medicine. 2020;30(1):7-9. Chinese. Available from: http:// dx.doi.org/10.12173/j.issn.1004-5511.2020.01.04

74. Song F, Shi N, Shan F, Zhang Z, Shen J, Lu H, et al. Emerging 2019 Novel Coronavirus (2019-nCoV) Pneumonia. Radiology. 2020;295(1):210-7. https://doi.org/10.1148/radiol.2020200274 PMID: 32027573

75. An P, Chen X, Jiang X, Su J, Xiao Y, Ding Y, et al. Clinical Features of 2019 Novel Coronavirus Pneumonia Presented Gastrointestinal Symptoms But Without Fever Onset. SSRN. 2020;3532530: (Preprint). Available from: http://dx.doi. org/10.2139/ssrn.3532530

76. Zhu N, Zhang D, Wang W, Li X, Yang B, Song J, et al. A novel coronavirus from patients with pneumonia in China, 2019. N Engl J Med. 2020;382(8):727-33. https://doi.org/10.1056/ NEJMoa2001017 PMID: 31978945

77. Holshue ML, DeBolt C, Lindquist S, Lofy KH, Wiesman J, Bruce $\mathrm{H}$, et al. First Case of 2019 Novel Coronavirus in the United States. N Engl J Med. 2020;382(10):929-36. https://doi. org/10.1056/NEJMoa2001191 PMID: 32004427

78. Huang C, Wang Y, Li X, Ren L, Zhao J, Hu Y, et al. Clinical features of patients infected with 2019 novel coronavirus in Wuhan, China. Lancet. 2020;395(10223):497-506. https://doi. org/10.1016/S0140-6736(20)30183-5 PMID: 31986264

79. Chen N, Zhou M, Dong X, Qu J, Gong F, Han Y, et al. Epidemiological and clinical characteristics of 99 cases of 2019 novel coronavirus pneumonia in Wuhan, China: a descriptive study. Lancet. 2020;395(10223):507-13. https:// doi.org/10.1016/S0140-6736(20)30211-7 PMID: 32007143

8o. Hui DSI, I Azhar E, Madani TA, Ntoumi F, Kock R, Dar O, et al. The continuing 2019-nCoV epidemic threat of novel coronaviruses to global health - The latest 2019 novel coronavirus outbreak in Wuhan, China. Int J Infect Dis. 2020;91:264-6. https://doi.org/10.1016/j.ijid.2020.01.009 PMID: 31953166

81. Liu SL, Saif L. Emerging viruses without borders: The Wuhan coronavirus. Viruses. 2020;12(2):130. https://doi.org/10.3390/ V12020130 PMID: 31979013

82. Chen P, Mao L, Nassis GP, Harmer P, Ainsworth BE, Li F. Coronavirus disease (COVID-19): The need to maintain regular physical activity while taking precautions. J Sport Health Sci. 2020;9(2):103-4. https://doi.org/10.1016/j.jshs.2020.02.001 PMID: 32099716

83. Liu SL. New virus in China requires international control effort. Nature. 2020;577(7791):472. https://doi.org/10.1038/d41586020-00135-Z PMID: 31956262

84. Gralinski LE, Menachery VD. Return of the Coronavirus: 2019-nCoV. Viruses. 2020;12(2):135. https://doi.org/10.3390/ V12020135 PMID: 31991541

85. Lippi G, Plebani M. The novel coronavirus (2019-nCoV) outbreak: think the unthinkable and be prepared to face the challenge. Diagnosis (Berl). 2020;0(0):/j/dx.ahead-of-print/ dx-2020-0015/dx-2020-0015.xml. https://doi.org/10.1515/dx2020-0015 PMID: 32083831

86. Long JB, Ehrenfeld JM. The role of augmented intelligence (AI) in detecting and preventing the spread of novel coronavirus. J Med Syst. 2020;44(3):59. https://doi.org/10.1007/s10916-0201536-6 PMID: 32020374

87. Nkengasong J. China's response to a novel coronavirus stands in stark contrast to the 2002 SARS outbreak response. Nat Med. 2020;26(3):310-1. https://doi.org/10.1038/s41591-0200771-1 PMID: 31988464

88. Jiang S, Xia S, Ying T, Lu L. A novel coronavirus (2019-nCoV) causing pneumonia-associated respiratory syndrome. Cell Mol Immunol. 2020. https://doi.org/10.1038/s41423-020-0372-4 PMID: 32024976 
89. Bassetti M, Vena A, Giacobbe DR. The novel Chinese coronavirus (2019-nCoV) infections: Challenges for fighting the storm. Eur J Clin Invest. 2020;50(3):e13209. https://doi. org/10.1111/eci.13209 PMID: 32003000

90. Yoo JH. The Fight against the 2019-nCoV Outbreak: an Arduous March Has Just Begun. J Korean Med Sci. 2020;35(4):e56. https://doi.org/10.3346/jkms.2020.35.e56 PMID: 31997618

91. Kickbusch I, Leung G. Response to the emerging novel coronavirus outbreak. BMJ. 2020;368:m406. https://doi. org/10.1136/bmj.m406 PMID: 32005675

92. Eurosurveillance Editorial Team. Note from the editors: World Health Organization declares novel coronavirus (2019-nCoV) sixth public health emergency of international concern. Euro Surveill. 2020;25(5). PMID: 32019636

93. The Lancet. Emerging understandings of 2019-nCoV. Lancet. 2020;395(10221):311. https://doi.org/10.1016/S01406736(20)30186-0 PMID: 31986259

94. Tang JW, Tambyah PA, Hui DSC. Emergence of a novel coronavirus causing respiratory illness from Wuhan, China. J Infect. 2020;80(3):350-71. https://doi.org/10.1016/j. jinf.2020.01.014 PMID: 32001309

95. Wang C, Horby PW, Hayden FG, Gao GF. A novel coronavirus outbreak of global health concern. Lancet. 2020;395(10223):470-3. https://doi.org/10.1016/S01406736(20)30185-9 PMID: 31986257

96. Kelvin DJ, Rubino S. Fear of the novel coronavirus. J Infect Dev Ctries. 2020;14(1):1-2. https://doi.org/10.3855/jidc.12496 PMID: 32088678

97. Lu H, Stratton CW, Tang YW. Outbreak of pneumonia of unknown etiology in Wuhan, China: The mystery and the miracle. J Med Virol. 2020;92(4):401-2. https://doi. org/10.1002/jmv.25678 PMID: 31950516

98. Perlman S. Another decade, another coronavirus. N Engl J Med. 2020;382(8):760-2. https://doi.org/10.1056/NEJMe2001126 PMID: 31978944

99. Cheng VCC, Wong SC, To KKW, Ho PL, Yuen KY. Preparedness and proactive infection control measures against the emerging novel coronavirus in China. J Hosp Infect. 2020;104(3):254-5. https://doi.org/10.1016/j.jhin.2020.01.010 PMID: 31962139

100. Duarte R, Furtado I, Sousa L, Carvalho CFA. The 2019 Novel Coronavirus (2019-nCoV): Novel Virus, Old Challenges. Acta Med Port. 2020;33(3):155. https://doi.org/10.20344/ amp.13547 PMID: 32023427

101. Zhang WH. [Identification of a novel coronavirus and the landscape of prevention and control of emerging infectious diseases]. Chin J Infect Dis. 2020,38:Epub ahead of print. Chinese. Available from: https://doi.org/10.376o/cma.j.is sn.1000-6680.2020.01.002

102. World Health Organization (WHO). Surveillance case definitions for human infection with novel coronavirus (nCoV). Interim guidance v2. Geneva: WHO; 15 Jan 2020. Available from: https://www.who.int/who-documents-detail/ surveillance-case-definitions-for-human-infection-withnovelcoronavirus-(ncov)

103. World Health Organization (WHO). Global Surveillance for human infection with novel coronavirus (2019-nCoV). Interim guidance. Geneva: WHO; 21 Jan 2020. Available from: https:// www.ephi.gov.et/images/20200121-global-surveillance-for2019-ncov.pdf

104. World Health Organization (WHO). Advice on the use of masks the community, during home care and in health care settings in the context of the novel coronavirus (2019-nCoV) outbreak. Interim guidance. Geneva: WHO; 29 Jan 2020. Available from: https://www.who.int/docs/default-source/documents/adviceon-the-use-of-masks-2019-ncov.pdf

105. World Health Organization (WHO). Clinical management of severe acute respiratory infection when novel coronavirus (2019-nCoV) infection is suspected. Interim guidance. Geneva: WHO; 28 Jan 2020. Available from: https://apps.who.int/iris/ handle/10665/330893

106. World Health Organization (WHO). National capacities review tool for a novel coronavirus (nCoV). Geneva: WHO; 10 Jan 2020. Available from: https://www.who.int/docs/defaultsource/coronaviruse/national-capacities-review-tool-for-anovel-coronavirus-ncov.pdf

107. World Health Organization (WHO). Household transmission investigation protocol for 2019-novel coronavirus (2019-nCoV) infection. Geneva: WHO; 25 Jan 2020. Available from: https:// www.who.int/publications-detail/household-transmissioninvestigation-protocol-for-2019-novel-coronavirus-(2019ncov)-infection

108. United States Centers for Disease Control and Prevention (US CDC). Update and Interim Guidance on Outbreak of 2019 Novel Coronavirus (2019-nCoV) in Wuhan, China. Atlanta: US CDC;
17 Jan 2020. Available from: https://emergency.cdc.gov/han/ hano0426.asp

109. United States Centers for Disease Control and Prevention (US CDC). Update and Interim Guidance on Outbreak of 2019 Novel Coronavirus (2019-nCoV). Atlanta: US CDC; 1 Feb 2020. Available from: https://emergency.cdc.gov/han/hano0427.asp

110. United States Centers for Disease Control and Prevention (US CDC). Lab Update: Interim Laboratory Biosafety Guidelines for Handling and Processing Specimens Associated with 2019 Novel Coronavirus (2019-nCoV). Atlanta: US CDC. [Accessed 6 Feb 2020]. Available from: https://www.cdc.gov/csels/dls/ locs/2020/interim lab biosafety guidelines for_handling and_processing_specimens_associated_with_2019_novel_coronavirus.html

111. United States Centers for Disease Control and Prevention (US CDC). Evaluating and Testing Persons for Coronavirus Disease 2019 (COVID-19). Atlanta: US CDC. [Accessed 6 Feb 2020]. Available from: https://www.cdc.gov/coronavirus/2019-ncov/ hcp/clinical-criteria.html

112. United States Centers for Disease Control and Prevention (US CDC). Interim Guidelines for Collecting, Handling, and Testing Clinical Specimens from Persons for Coronavirus Disease 2019 (COVID-19). Atlanta: US CDC. [Accessed 6 Feb 2020]. Available from: https://www.cdc.gov/coronavirus/2019-ncov/lab/ guidelines-clinical-specimens.html

113. United States Centers for Disease Control and Prevention (US CDC). Interim Guidance for Ships on Managing Suspected Coronavirus Disease 2019. Atlanta: US CDC. [Accessed 6 Feb 2020]. Available from: https://www.cdc. gov/quarantine/maritime/recommendations-for-ships. html?CDC_AA_refVal=https\%3A\%2F\%2Fwww.cdc. gov $\% 2$ Fcoronavirus $\% 2$ F2019-ncov $\% 2$ Ftravelers $\% 2$ Frecommend ations-for-ships.html

114. United States Centers for Disease Control and Prevention (US CDC). Interim Clinical Guidance for Management of Patients with Confirmed 2019 Coronavirus Disease (COVID-19). Atlanta: US CDC. [Accessed 6 Feb 2020]. Available from: https:// www.cdc.gov/coronavirus/2019-ncov/hcp/clinical-guidancemanagement-patients.html

115. Wang YG, Qi WS, Ma JJ, Ruan LG, Lu YR, Li XC, et al. [Clinical characteristics and syndrome differentiation of new coronavirus (2019-nCoV) pneumonia in traditional Chinese medicine]. J Tradit Chin Med. 2020,61(04),281-285. Chinese. Available from: http://kns.cnki.net/KCMS/detail/11.2166 .R.20200129.1258.002.html.

116.Jin YH, Lin C, Cheng ZS, Cheng H, Deng T, Fan YP, et al. [A rapid advice guideline for the diagnosis and treatment of 2019 novel coronavirus (2019-nCoV) infected pneumonia (Standard version)]. Medical Journal of Chinese People's Liberation Army. 2020;45(1):1-21. Chinese. Available from: http://www.cnki.com. cn/Article/CJFDTotal-JFJY202001002.htm.

117. Li SY, Huang WZ, Liao XL, Li DD, Du LY, Song J], et al. [Disease control of 2019-novel coronavirus infection in hospital: West China urgent recommendation]. Chinese Journal of EvidenceBased Medicine. 2020;20(2):125-133. Chinese. Available from: http://www.cjebm.com/article/10.7507/1672-2531.202001121

118. Li TS, Cao W, Weng L, Fan HW. Shi JH. [Peking Union Medical College Hospital's proposal for the diagnosis and treatment of novel coronavirus-infected pneumonia (V2.0)]. Medical Journal of Peking Union Medical College Hospital. 2020;01(01):1-5. Chinese. Available from: https://kns.cnki.net/KCMS/detail/11. 5882.r.20200130.1430.002.html

119. Ni Z, Luo FM, Wang JM, Liu TT, Zhang TX, Yang W, et al. [Recommendations for nebulization therapy in patients with novel coronavirus pneumonia]. Chinese Journal of Respiratory and Critical Care Medicine. 2020;19(02):120-124. Chinese. Available from: https://kns.cnki.net/KCMS/detail/detail. aspx $? \mathrm{db}$ code $=$ CJFQ \&dbname $=$ CJFDAUTO\&filename $=$ ZGHW202$002009 \& v=M j M_{5} O D U_{3} c W Z Z K 1$ pyRnlubVVyckFQeXJEZWJHNEh OSE1yWTIGYIISOGVYMUx1eFITNoRoMVQzcVRyVooxRnJDVVI=

120. Zhao DC, Jin RM, Liu ZS, Yin W. [Recommendation for the diagnosis and treatment of novel coronavirus infection in children in Hubei (trial first version)]. Chin J Contemp Pediatr. 2020;22(02):96-9. Chinese. Available from: https://kns.cnki. net $/$ KCMS/detail/detail.aspx ddbcode $=C J F Q \&$ dbname $=C J F D$ AUTO\&filename $=$ DDKZ202002004\&v=MDE1NzQ5RIJUjhIWDF MdXhZUzdEaDFUM3FUcldNMUZyQ ${ }_{1}$ SN $_{3}$ FmWStackZ 5 bm1WT HpCSVNuQWRMRzRITkhNclk=

121. Wang JH, Bao L, Shi Y. [NICU emergency prepardness plan during the epidemic novel coronavirus infection]. Chin J Contemp Pediatr. 2020;22(02):91-5. Chinese. Available from: https:// kns.cnki.net/KCMS/detail/detail.aspx?dbcode $=C J F Q \& d b n a m-$ $\mathrm{e}=$ CJFDAUTO\&filename $=$ DDKZ202002002\&v $=\mathrm{MTI}_{2} \mathrm{MjIXTHV}_{4}$ WVM $_{3} R_{\text {RG }}$ xVDNxVHJXTTFGckNVUjdxZlkrWnJGeW5uVXI3TEITb kFkTECOSE5ITXJZOUZab1/4ZVg=

122. Shi Y, Fu JH, Wang LS, Yang J, Du LZ, Zhou WH. [Novel Coronavirus Infection Prevention and Control Plan for 
Newborns in Perinatal Period (First Edition)]. Chin J Contemp Pediatr. 2020;22(02):87-90. Chinese. Available from: https:// kns.cnki.net/KCMS/detail/detail.aspx?dbcode $=$ CJFQ\&d bname $=$ CJFDAUTO\&filename $=$ DDKZ202002001\&V $=$ MTkyMjdT NoRoMVQzcVRyVooxRnJDVVI3cWZZK1pyRnlublZiekpJU25BZEx HNEhOSE1yWTIGWIISOGVYMUx1eFk=

123. Peng X, Hu Y, Yao JH, Liu W, Li C, Zhang X, et al. [Emergency nursing management for the prevention of novel coronavirus infection in oral and maxillofacial surgery]. Nursing Research. 2020;34(03):365-367. Chinese. Available from: https://kns. cnki.net/KCMS/detail/detail.aspx?dbcode $=C J F Q \&$ dbname $=C$ JFDAUTO\&filename $=$ SXHZ202003002\&V=MTM5OTNJOUZab1 4ZVgxTHV4WVM3RGgxVDNxVHJXTTFGckNVUjdxZlkrWnJGeW5 nVTd6To5qWERkTEcoSE5ITXI=

124. Chen T, Chen G, Guo W, Xie M, Ma K, Yan L, et al. [A quick guide to diagnosis and treatment of pneumonia with nove coronavirus infections (Third Edition)]. Herald of Medicine. 2020;39(03):305-307. Chinese. Available from: http://kns. cnki.net/kcms/detail/42.1293.r.20200130.1803.002.html

125. Chen ZM, Fu JF, Shu Q, Chen YH, Hua CZ, Li FB, et al. Diagnosis and treatment recommendations for pediatric respiratory infection caused by the 2019 novel coronavirus. World J Pediatr. 2020;5. https://doi.org/10.1007/s12519-020-00345-5 PMID: 32026148

126. Wang XY, Wu J, Lu XH, Zhang RF, Zhou Y, Li LY, et al. [Recommended strategies for maternal management of novel coronavirus (2019-nCoV) infection in Henan Province]. Herald of Medicine. 2020;55(02):200-202. Chinese. Available from: https://kns.cnki.net/KCMS/detail/41.1340 .r.20200328.1323.012.html

127. Fudan University. [Quick screening and management of children with suspected or confirmed COVID-19: A rapid advice guideline]. Herald of Medicine. 2020;15(01):1-4. Chinese. Available from: http://www.cjebp.net/CN/Y2020/V15//1/1

128. Wang YT, Huang WZ, Song J,, Li SY, Wang YN, Du LY, et al. [Graded personal protection plan for prevention of novel coronavirus pneumonia in medial personnel in West China Hospital]. Chinese Journal of Evidence-Based Medicine. 2020;20(03):369-372. Chinese. Available from: http://www. cjebm.com/article/10.7507/1672-2531.202001120

129. Schünemann HJ, Hill SR, Kakad M, Vist GE, Bellamy R, Stockman L, et al. Transparent development of the WHO rapid advice guidelines. PLoS Med. 2007;4(5):e119. https://doi. org/10.1371/journal.pmed.0040119 PMID: 17535099

130. Communicable Diseases Network Australia (CDNA). Coronavirus Disease 2019 (COVID-19). CDNA National Guidelines for Public Health Units. Canberra: CDNA. [Accessed 7 Feb 2020]. Available from: https://www1.health.gov.au/ internet/main/publishing.nsf/Content/cdna-song-novelcoronavirus.htm

131. Cochrane Network. Living mapping and living network meta-analysis of Covid-19 studies. [Accessed 14 Apr 2020]. Available from: https://covid-nma.com/

132. Rawlinson C, Bloom T. New preprint server for medical research. BMJ. 2019;365:l2301. https://doi.org/10.1136/bmj. l2301 PMID: 31167753

133. Johansson MA, Reich NG, Meyers LA, Lipsitch M. Preprints: An underutilized mechanism to accelerate outbreak science. PLoS Med. 2018;15(4):e1002549. https://doi.org/10.1371/journal. pmed.1002549 PMID: 29614073

134. Committee on Standards for Developing Trustworthy Clinical Practice Guidelines/Board on Health Care Services/ Institute of Medicine. Clinical practice guidelines we can trust. Washington: The National Academies Press; 2011. Available from: https://www.nap.edu/catalog/13058/ clinical-practice-guidelines-we-can-trust

135. Garritty CM, Norris SL, Moher D. Developing WHO rapid advice guidelines in the setting of a public health emergency. J Clin Epidemiol. 2017;82:47-60. https://doi.org/10.1016/j. jclinepi.2016.08.010 PMID: 27591906

\section{License, supplementary material and copyright}

This is an open-access article distributed under the terms of the Creative Commons Attribution (CC BY 4.0) Licence. You may share and adapt the material, but must give appropriate credit to the source, provide a link to the licence and indicate if changes were made.

Any supplementary material referenced in the article can be found in the online version.
This article is copyright of the authors or their affiliated institutions, 2020. 